\title{
Courage Character Education Values in Mata dan Rahasia Pulau Gapi A Novel by Okky Madasari
}

\author{
Luvi Kurnia Permana ${ }^{1}$, Sarwiji Suwandi ${ }^{2}$, Atikah Anindyarini ${ }^{3}$ \\ \{Luvikurniapermana@student.uns.ac.id ${ }^{1}$, Sarwijiswan@yahoo.com², \\ Atikahanindyarini@gmai.com $3^{3}$ \} \\ ${ }^{1,2.3}$ Universitas Sebelas Maret, Indonesia
}

\begin{abstract}
This study aims to explain the courage character education values in Mata dan RahasiaPulau Gapi, a novel by Okky Madasari. The novel is choosen due to its various character education values, especially courage character education values. The value is utilized to increase learners' character. This study employ descriptive qualitative method. The subject of this research is Mata dan Rahasia Pulau Gapia novel by Okky Madasari and the object is character education values that focused on the courage of the character. The data is generated using non-interactive analysis and note-taking technique. Non-interactive analysis is utilized to capture the courage character value.Note-taking technique is utilized to validate the data using triangulation. Source triangulation is utilized to validate the data using content analysis approach to this novel discourse by hermeneutic perusal. The result revealed that there are six courage education value, that are : (1) courage;(2) tenacity;(3) patience; (4) perseverance; (5) endurance; and (6) self-confidence.
\end{abstract}

Keywords: character education, educational value, character, novel

\section{INTRODUCTION}

This rapid development era needs an encouragement to develop the community due to the importance of the increasing quality of individuals that forming the society. Education is a conscious effort invest good values. For example, cultural values and religious values that are able to form students to have positive characters. The characterssupporttheir growth and development. Thus, they can be successful in life, both in this world and hereafter[1]. The aim of creating a quality and competent individual community through education has recently been on the agenda of teaching programs in Turkey. In line with development in learning programs, studies in the field of Education practitioners competency are also increasing. Some studies are contributing to the character education to the social competence of elementary students. Nevertheless, contributions will still require empirical substantiation and generalization because previous research has not been uniformly rigorous and supportive [2].

Meanwhile, the empirical conditions indicate that character education is not yet effective. Students' weak personalities, learning enthusiasm, discipline, ethics, and hard work are some of proofs. Thus, they are not ready to face life, and are easily influenced by negative culture [3]. In line with this condition, character education can be taught in several ways, one of which is through literature. Literature provide benefits for the author and also the reader. 
Authors can express all feelings, ideas, and concepts of noble values, beliefs and aesthetic values through literature [4]. According to the psychological science or psychology point of view, the valuable and quality literature are those can foster a real and clear picture of the character of figures, for example about confusion and chaos and the turmoil of the mind and human spiritual that formed in the characters [5]. The availability of many novels that contains character education values is fresh air for the Education practitioners[6]. In addition, literaturebased learning of youth literature can also be directed to the efforts ofeducation implementation and character development of students [7].

Literature have an important role in the world of education because literary works contain the writer's life reflection which influenced by the culture and social conditions of the writer. Education practitioners can use it as a learning media to deliver about character education through literature. Literary works are imaginative utterances that make students not feel bored in the learning process [8]. The previous study utilize high school (SMA) literature as an object by observing the character value in the literature[9]. Furthermore, the other research utilize proverb. The local children in Dayak, Central Borneo are able to apply noble character values derived by ancestors[10]. A study about Canting novel by Arswendo Atmowiloto emphasize on Javanese cultural value aspect[11]. The study showed that there is displacement that cause a change in the application of character values in Javanese culture. This study focus on novel because further, this research can be utilized as learning materials to students.

Novel is one of popular literature. The novel is a literary work by narrating a writing into a story that brings the reader in and becomes a witness of the story in the novel [12]. One of the novels that can be used for research is Mata dan Rahasia Pulau Gapi, the second novel from the series of children's novels by Okky Madasari. This novel was published by PT Gramedia Pustaka Umum in 2018[13]. Researcher chose the novel Mata dan Rahasia Pulau Gapi by Okky Madasari due to the stories in the novel that contain many character education values. From some character values, researcher focuses on the courage character values. The novel is also suitable to be used as a medium of learning by the Education practitioners in the learning process and the Education practitioners can take lessons from the novel's story.Courage character education values in the novel not only embedded in one character, but also in several characters. Thus, the research focuses on the whole novel. The courage character is explained implicitly and explicitly.

\section{METHOD}

Descriptive research is research that describe a phenomena, an indication, and an event. Descriptive research focuses on actual problems as they were at the time of the study . Descriptive research was chosen because it is able to describe courage character education value entirely in the novel Mata dan Rahasia Pulau Gapi by Okky Madasari. In addition, descriptive research also able to systematically describe the facts and characters of objects or subjects that are precisely examined. The subject of this research is Mata dan Rahasia Pulau Gapi by Okky Madasari. The selection of the novel as the subject of this study because researchers are interested in presenting the novel's story. Meanwhile, the object of research in this study was Gapi by Okky Madasari.

Data collection methods are ways that researchers utilize to collect data. The data collection method is suited with the problem that wanted to be studied and solved in this study. This study employ non-interactive analysis and note-taking techniques as data analysis techniques. Non-interactive analysis technique is employed to determine the courage character values. The note taking is applied to validate the data by triangulation. Source triangulation is 
used to validate data by using a content analysis or content analysis approach to the discourse in the novel by conducting hermeneutic readings.

\section{RESULT AND DISCUSSION}

This research was conducted because previous research found several constraint in studying literary appreciation. The results of that study that is in the subject of literature appreciation and character education include (1) Students are tend to not have pluralistic attitude. Some students do not understand the meaning of character education and cultural values, students have less reading interest; (2) Some lecturers have taught cooperative literary appreciation. However, they have no time to study the theory of cooperative learning models; (3) Various literary appreciation teaching materials can be found in private universities; (4) There is no teaching material for literature appreciation that uses cooperative models as a basis for cultural values and character education.

Based on previous research, researchers are interested in conducting a study about character education research. This study refers to the the value of character educationstated by Thomas Lickona in his book "Character Matters: Personal Character" which consists of 10 character education values[14]. However, researchers only focus on courage character education value. The research results on the novel Mata dan Rahasia Pulau Gapi by Okky Madasari reveal courage character education values that are: (1) courage; (2) tenacity; (3) patience; (4) perseverance; (5) endurance; and (6) self-confidence.

\subsection{Courage Value}

Courage or "keberanian" and "keteguhan hati". This value needs to be engaged in the face of fear, traits of doubt, nervousness and indecision, and other interfere characteristic. Children need to be encouraged and motivated to practice using their intelligence. This is proven in the following data.

"Awalnya ia pun ragu. Apakah istrinya akan mau pindah ke pulau yang jauh, meninggalkan Ibukota yang menyediakan segalanya? Ternyata, di luar dugaan, istrinya berteriak kegirangan. ”( $p .16)$

The quote above contains the courage character education value, because the figure of the father dared to make decision to his wife to move to the eastern island of Java, which is far from the capital city.

"Kala orang-orang dari negeri jauh menemukan pulau indah ini dan mau menguasainya, Sang sultan segera memerintahkan prajurit-prajurit untuk menyembunyikan hartanya di Tolire." (p. 27)

The quote above contains courage value, because the sultan is the ruler of Tolire Island. He has great responsibility and insists to guarding and preserving the wealth of Tolire Island.

\subsection{Tenacity value}

The tenacity value in the novel showed by several actions from the character that already try with perseverance to obtain what they want.Tenacity is a behavior that shows genuine effort in overcoming various barriers of learning and assignment. Also, completing assignment as well as possible. This value can be proven in the following data [15].

"Matara telah bekerja keras sekian lama, terutama pada hari-hari menjelang ujian akhir, untuk bisa mendapat nilai setinggi-tingginya agar bisa diterima di SMP yang diidamkannya itu." (p. 12) 
The quote above proves that the character Matara has a tenacious nature or is not easily discouraged. Matara is keep learning to obtain satisfactory results and can be accepted in the famous favorite junior high school in Jakarta city.

"Tak ada kata puas selama masih ada yang salah dalam lembar-lembar soal yang dikerjakan Matara." (p. 23)

The quotes above contains tenacity value because we have to keep learning until we master and understand on something. Being not easily satisfied and keep trying are two of tenacity indicators. This is what described by the character of Matara.

\subsection{Patience Value}

The patience value in this novel is explained by the character of Matara and Mama Matara who failed. Patience is an attitude of holding back emotions and desires, and staying in difficult situations by not complaining. This can be proven in the following data.

"Baginya, kegagalan ini bukan hanya kegagalan Matara, tapi juga kegagalan sebagai orangtuanya. Dia tidak memarahi anaknya, tapi dia jadi menangis berhari-hari dan terus menyalahkan diri sendiri." (p. 13)

"Ia tahu mamanya benar-benar sedih, kecewa, dan marah atas kegagalannya masuk sekolah favorit. Ia justru heran kok mamanya bisa kembali baik-baik saja dan seolah lupa dengan masalah anaknya itu."(p. 22)

The two quotes above containpatience character education value. Matara's mother did not blame Matara about the incident, because Matara had tried her best and studied every day to be able to enter the favorite junior high school. Matara's mother blamed herself for not being able to guide her child to be admitted into the number one favorite junior high school in Jakarta.

\subsection{Perseverance Value}

Perseverance or "ketekunan". How to encourage students to be more diligent and continuing their effort to increase courage and perseverance. They need to be guided and directed by giving positive examples, putting forward the principle of "Tut Wuri Handayani" [14]. This can be proven in the following line.

"Setiap hari, dari pagi hingga siang, Matara membaca banyak buku dan berlatih mengerjakan banyak soal, terutama soal-soal IPA dan matematika."(p. 23)

The quote above contains the courage character education value of perseverance aspect, because that quote tells that the character of Matara is diligent.

"Mama Mataraa kembali menyodorkan soal-soal untuk dikerjakan Matara. Matara mulai mengerjakan soal-soal dengan tekun." (p. 30)

The quote above contains perseverance value, because in any situation or condition Matara must keep studying at the school that Mama Matara founded without being able to refuse for any reason. 


\subsection{Endurance Value}

Endurance is one of courage value aspect that relate to mental endurance or soul from the character. Endurance is the ability of an organism to move itself and stay active for long periods of time. This can be proven in the following line.

"Matara, si anak baru di pulau, menjadi gelisah dan tak betah. Tak ada AC di rumah yang mereka tempati. Hanya kipas angin yang sama sekali tak mengurangi rasa panas yang menyiksa."(p. 29)

The quote above contains endurance character education value. It is indicated by the atmosphere of the island. The temperature is getting hot day by day that induce indefinite immune system.

"Dalam situasi yang serba panas seperti itu, sekolah Matara masih harus tetap berjalan seperti biasa." (p. 29)

The quote above shows the value of endurance. In very hot situations and indefinite weather, Matara must stay in school. There is no holiday for the school that established by Matara's mother.

\subsection{Self-Confidence Value}

Self-confidence value is confidence that is related to the mental attitude that makes someone believe in himself that he is able to do a certain thing. Confident people have positive self-concept, have strong beliefs in themselves, and have accurate knowledge of their abilities [15]. This can be proven in the following line.

"Ia akan mengajari sendiri anaknya. Ia akan menjadikan anaknya yang paling pintar. Ia akan membalas kegagalan anaknya diterima di sekolah favorit dengan caranya." (p. 23)

The quote contains self-confidence character education value, because Matara's mother has high self-confidence to make her child become the smartest person and repay the failure that happened to her child, Matara.

\section{CONCLUSION}

It can be concluded that in Mata dan RahasiaPulau Gapi, a novel by Okky Madasari, there aresix courage education aspects that consist of six values that are: (1) courage; (2) tenacity; (3) patience; (4) perseverance; (5) endurance; and (6) self-confidence. The six courage education values is embedded in attitude and behavior of the novel character. From reading activity, readers are invited to understand courage character aspects of the character.

Based on the above conclusions the writer can give advice to educator practitioners. First, educator practitioners should give assignments to students to read the novel and imitate the good attitude contained in the novel. Second, educator practitioners can take lessons after reading the novel to be used as a reference in the learning process. Third, students can adopt the values of character education contained in the novel to be used as an example in everyday life. 


\section{REFERENCES}

[1] M. Ülger, S. Yiğittir, and O. Ercan, "Secondary School Teachers' Beliefs on Character Education Competency," Procedia - Soc. Behav. Sci., 2014.

[2] C. Lucas, T. Power, C. Hayes, and C. Ferguson, "Development of the RIPE model (Reflective Interprofessional Education Model) to enhance interprofessional collaboration," Research in Social and Administrative Pharmacy. 2019.

[3] F. Nugrahani, "PENDIDIKAN KARAKTER MELALUI PEMBELAJARAN BAHASA INDONESIA DENGAN MATERI MEMBACA NOVEL SASTRA," Edudikara, Vol 2 (2); p.113-124, vol. 2, no. 2, pp. 113-124, 2017.

[4] S. Sulastri and A. A. Alimin, "Nilai Pendidikan Karakter Kerja Keras Dalam Novel 2 Karya Donny Dhirgantoro," Pendiidikan Bhs., vol. 6, no. 2, pp. 156-168, 2017.

[5] S. dan T. Wahyukti, "TINJAUAN KEKERASAN DAN PSIKOLOGIS PADA NOVEL TEMBANG ILALANG KARYA MD AMINUDIN," FKIP Univ. Muhammadiyah Purwokerto.

[6] W. D. Pusvita, "NILAI-NILAI PENDIDIKAN KARAKTER PADA NOVEL AYAH KARYA ANDREA HIRATA," LEKSEMA J. Bhs. dan Sastra, 2018.

[7] B. Nurgiyantoro and A. Efendi, "PRIORITAS PENENTUAN NILAI PENDIDIKAN KARAKTER DALAM PEMBELAJARAN SASTRA REMAJA,” J. Cakrawala Pendidik., 2013.

[8] R. ABDUL FATAH, "PENDIDIKAN KARAKTER DALAM NOVEL MAHAMIMPI ANAK NEGERI TINJAUAN PSIKOLOGI SASTRA," Gramatika STKIP PGRI Sumatera Barat, 2018.

[9] L. Septiningsih, "Membangun Karakter Bangsa Berbasis Sastra: Kajian terhadap Materi Karya Sastra di Sekolah Menengah Atas," J. Pendidik. dan Kebud., 2015.

[10] R. Hery Budhiono, "PERIBAHASA: KEARIFAN LOKAL PEMBENTUK KARAKTER ANAK-ANAK DAYAK MAANYAN DI KALIMANTAN TENGAH," Ranah J. Kaji. Bhs., 2016.

[11] E. Wahyuningsi, "PERGESERAN NILAI BUDAYA JAWA DALAM NOVEL CANTING KARYA ARSWENDO ATMOWILOTO: SUATU KAJIAN ANTROPOLOGI SASTRA," J. KATA, 2018.

[12] N. luh L. A. Dewi, I. B. Putrayasa, and I. G. Nurjaya, "Analisis Nilai-Nilai Pendidikan Karakter Novel Sepatu Dahlan Karya Khrisna Pabichara Dan Karakter Sekolah Di Indonesia," e-Jurnal Pendidik. dan Sastra Indones., 2014.

[13] O. Madasari, MATA DAN RAHASIA PULAU GAPI. Jakarta: Gramedia, 2018.

[14] T. Lickona, "Character Education: The Cultivation of Virtue," in Instructional-design theories and models: A new paradigm of instructional theory, Vol.II., 1999.

[15] K. Saddhono and M. Rohmadi, "A Sociolinguistics Study on the Use of the Javanese Language in the Learning Process in Primary Schools in Surakarta, Central Java, Indonesia." Int. Edu. Stu., vol. 7 no.6 pp 25-30, 2014 